Cumhuriyet International Journal of Education-CIJE

e-ISSN: 2147-1606

Vol 3 (4), 2014, 49 - 60

\title{
Primary Teachers Manual 1st Class Turkish and Fitness Level Student Work Book of the Constructivist Learning Approach
}

\author{
Mehmet Akif BİRCAN ${ }^{1}$, Yasin GÖKBULUT²
}

\section{Summary}

Today it remains insufficient to meet the needs of the era of the traditional educational approach, constructivist approach, multiple intelligences, student-centered education, new approaches such as brain-based learning has come to the fore. This radical change in understanding experienced mental skills such as language and instead change the student's behavior in the educational process giving weight to the development of our country has affected education programs and constructivist learning approach has been implemented from 2005-2006 (MEB İlköğretim Türkçe Dersi Öğretim Programı ve Kılavuzu, 2009:9-11). In the constructivist learning approach is not taken as information from an external source, instead of individual information or reviews existing information reveals itself. Given this aspect of the constructivist approach as teachers and course change the role of the student's role has changed the book. Textbooks in the configuration process information to students, guiding them to think, to help gain a critical perspective, contributing to making evaluation with multi-perspective has become a teaching tool (Ocak and Dai, 2010: 3). All information in line; prepared on the basis of a constructivist approach with programs, regulation of textbooks and educational materials has brought the necessity. The purpose of this research is the Board of Education Ministry of the Presidency of the date 27.07.2011 and No. 97 boards imprinted with the decision of Primary 1 class Turkish student workbooks and teacher's book is to determine the suitability of constructivist learning approach. In the light of the information obtained to provide information for the book to be prepared and to contribute towards the new Turkish student workbooks and teacher's guide book. 27/07/2011 Chairman of the Board of Education and the Ministry of date imprinted with the board's decision No. 97 Elementary School 1st Class Turkish student workbooks and teacher's books are sources of research data. Data collection and analysis were utilized in this research stage in the document review process. Investigation document analysis includes analysis of written materials containing information about the targeted cases and cases (Yıldırım and Şimşek, 2006). Student Workbook and Teacher's Guidebook evaluation Akkocaoğlu (2009), which was developed by the constructivist learning approach identified by Criteria were used. Akkocaoğlu (2009), a variety of resources related to the constructivist learning approach during development was examined by criteria. Based on the information obtained from the constructivist learning approach to represent the criteria and guidelines to assure that the criteria identified in the course of the book is set. Found to correspond to what event or events are taking views from the 5 experts in the field of the final 15 degree Elementary Student Workbook and Teacher's Guide Book prepared to ensure the content validity of the scale. Akkocaoğlu by the constructive learning approach (2009) determined by criteria consists of 15 items. This article from the "teacher learning and change their evaluation activities, or to give a chance to submit a proposal to select" criterion is used only to assess the Primary 1 Grade Turkish Teacher's Guide Book. The other 14 measures 1 Grade Turkish Elementary Teacher's Guide and Book is common for students Workbook. Primary 1st Grade Turkish Teacher's Guide and Student Workbook Books were examined separately. Books; Ataturk, Love, Health and Environment, Games \& Sports is 4 'consists Theme. All activities included in these themes, questions, instructions, methods and techniques, tools

\footnotetext{
${ }^{1}$ Ministry Of National Education, mehmetakifbircan@hotmail.com.tr

2 Assist. Prof. GOP University, Faculty of Education, yasingkbulut@yahoo.com
} 
and materials, texts, assessment and evaluation studies, preparatory studies identified was found that they corresponded to what extent or degree. During the conduct of the extent of the primary 1st class student work and teacher's book which is the theme of each criteria, the criteria given number 1 is made up of 15 . These numbers meet the criteria examined in the book is marked as text or numeric on the event. The criteria for each theme and then collected data were entered into a Microsoft Office Excel. How many times in each theme each criterion to quantify the percentage of the obtained data can be seen and seen in all measures calculated and presented in Microsoft Office Excel. This digital data is followed by interpretation of the data. According to the findings of the results obtained in this study; Examine the Student Workbook and Teacher's Guide Book, the constructivist learning theory has been involved in activities for the criteria to be included in textbooks prepared in the light. However, these criteria are different from each other in number and rate of frequency and rate of occurrence. In this case, the book reflects all of the examined constructivist learning standards; but the big difference between the rates for the criteria constructivist book shows that the criteria is sufficient for partial. 